\title{
Testing the Neutrality of Money towards Real Output: A Case of Malaysia
}

\author{
Yet Huat Sam ${ }^{1 *}$, Caroline Geetha1, Vivin Vincent Chandran ${ }^{1}$ and Amran Ahmed ${ }^{2}$
}

${ }^{1}$ University of Malaysia Sabah, Malaysia

${ }^{2}$ University of Malaysia Perlis, Malaysia

\begin{abstract}
Neutrality of money has a long debate towards real output. Rational expectation theory states, money is neutral at all time, however, short run effect is mainly caused by the unanticipated money supply. On the opposite stance, based on the theory of rational belief, money is neutral neither in short run nor long run. This paper has examined the long run behaviour of monetary aggregates towards Malaysia economic through quarterly data ranging from 1996 to 2014. Unanticipated money supply which is obtained based on Barro model; M1, M2 and M3 have been tested under the Vector Error Correction Model. Time dummy has been included to accommodate the period of financial crises and fixed exchange rate regime era. However, there is little evidence to support the view of neutrality of money hold in Malaysia. The findings provide evidence to support the decision of Malaysia authority getting out from rigid exchange rate policy since 2005 .
\end{abstract}

Keywords: Neutrality of money; Unanticipated money supply; Exchange rate regime

\section{Introduction}

Keynesians believe money is neutral in both short run and long run; therefore, any increment of money supply does not alter the real macroeconomic variables such as, real output or real unemployment level. The grounded theory of Keynesians is based on Quantity Theory of Money. Furthermore, as predicted by Keynesian aggregate supply, there exist a trade-off between inflation rate and unemployment rate. This is because the inverse relationship between inflation rate and unemployment observed by Phillip Curve. However, this approach is insufficient to explain the Phillip Curve in long run, when, market agents receive full enough information to act according to the changes of money aggregation. Thus, monetarists pioneered by Friedman [18] have stood up to fix this puzzle. The argument of monetarists is that, the information asymmetric among market agents do not hold for long term. Furthermore, according to Miller and Van Hoose [9] monetarists blended the idea of Keynesian theory and classical theory to explain the short run and long run of Phillip Curve. Later, Lucas [10] and Sargent \& Wallace [11] developed the Rational Expectation Hypothesis to enhance the explanation of short run changes between money supply and real macroeconomic variable. Rational Expectation Hypothesis brought in the concept of unanticipated money supply that gave unexpected changes towards the real macroeconomic variables in short run. Therefore, this also explains authorities tend to keep the details of implemented policies away from public in order to avoid unexpected result, such as, keeping the basket weight confidentially while implementing basket pegged exchange rate regime. However, to the other end, non-neutralists [4-6] argued that money is not neutral at all time. This group of scholars claimed that, policy makers should employ discretionary policy to achieve macroeconomic objective, specifically in term of mazimizationf of employment and economic growth sustainability.

On the theoretical ground, Keynesian believes pricing mechanism work better than government intervention, which comprised the Keynesian's 'invincible hand' in the market. Price equilibrium restores automatically, therefore, floating exchange rate regime, in which exchange rate is determined by the market force of demand and supply, is viewed as the optimum exchange rate regime to be implemented. Furthermore, floating exchange rate regime comes with high stability of real exchange rates. However McKinnon, et al. [12] claimed that, fluctuation from nominal exchange rate would be transferred to the domestic price directly and real exchange rate is maintained at fixed rate. Therefore, policy makers should implement strict monetary policy and fixed exchange rate regime to control the prices under the Keynesian's theory McKinnon, et al. [12] However, non-neutralists who violate the classical view of Keynesian's assumption, argued that, market should be non-homogeneous, where, information is imperfect, agents are behave in the different way and the changes of relative prices has to be taken into account when money fluctuation takes its place. Non-neutralists also put doubt on the price mechanism which acts as the 'invincible hand' in the market. Therefore, suggested by nonneutralists, intervention is necessary to adjust the real macroeconomic variables, specifically the discretionary adjustment. Then, exchange rate policy can be treated as the nominal anchor to achieve macroeconomic objectives. With the above mentioned reasons, non-neutralists advocate the fixed but adjustable exchange rate regime is more suitable to compliment the monetary policy. Mishkin, et al. [13] emphasized that, the McKinnon (1988)'s fixed exchange rate regime under the Keynesian's theory is different from fixed exchange rate regime proposed by the non-neutralists. The former one is considered as the hard pegged, however, the later is classified as the intermediate regime where the fixed rate is adjustable from time to time.

Based on the Rational Expectation of Theory, unanticipated money supply would alter the real macroeconomic variable in short run. Thus, it forms the middle ground theorists between Keynesians and monetarists. Theorists Williamson, Krugman [14,15] who argued money is neutral in long run only, has agreed with the stance of Keynesian's theory in long run but hold the Rational Expectation theory for the short run. This group of theorists, generally, agree with the classical economic theory towards the money. In short run, due to the price rigidness, market failure and time lagged of responses, thus, money does affect real economic permanently. Furthermore, Mollo,

*Corresponding author: Yet Huat Sam, University of Malaysia Sabah, Kota Kinabalu, Sabah, Malaysia, Tel: (+6088) 320000 ext 2240; Fax: (+6088) 320232; E-mail: sam.yethuat@gmail.com

Received November 06, 2015; Accepted November 16, 2015; Published November 21, 2015

Citation: Sam YH, Geetha C, Chandran VV, Ahmed A (2015) Testing the Neutrality of Money towards Real Output: A Case of Malaysia. Int J Econ Manag Sci 4: 298. doi:10.4172/21626359.1000298

Copyright: (c) 2015 Sam YH, et al. This is an open-access article distributed under the terms of the Creative Commons Attribution License, which permits unrestricted use, distribution, and reproduction in any medium, provided the original author and source are credited. 
Silva, \& Torrance [4] claimed that, the changes of relative price between non-tradable goods and tradable goods that caused by the changes of demand of goods would influence the fluctuaton of exchange rate regime. The changes of balance of payment between the countries would be adjusted alongside with exchange rate and the effect would be delayed. Thus, floating exchange rate regime would be the choice amongts these groups of theorists. Floating exchange rate regime, in long run, is determined by the price mechanism, however, in the short run, Krugman [15] claimed that, minimal government operation is needed, but, prolong intervention may increase the possibility of financial crises.

Malaysia has implemented managed floating exchange rate regime since 2005. BNM [16] claimed that, decision to exit from fixed exchange rate regime that implemented since 1997 is based on the promising performance economic growth. The objective of Bank Negara Malaysia in the exchange rate policy is achieving economic growth while maintain stability of exchange rate. However, in mid-2015, economic Malaysia has experienced sharp deterioration. The revenue from oil and gas industry that build up more than 25 percent of government revenue has turned sour due to the falling oil prices. Furthermore, as the most heavily trading partner, China is also experiencing economy slowdown that pulls down Malaysia's current account to shallow surpluses [17] Thus, Malaysian currency has reported a decrement of more than 45 percent to RM 4.2190 to USD 1 on $2^{\text {nd }}$ September, 2015, compared to the historical highest since May, 2013 [18]. Furthermore, the BNM [18] stated, market would eventually determine the exchange rate in the long run. However, based on the market watch, there are about USD 10 billion was used to defend the position of Ringgit Malaysia by August, 2015. Exchange rate implies the role of external trade of a nation. Exchange rate also influences the output production through depreciation or devaluation of domestic currency. However, as the exchange rate receives overwhelming pressure, the possibility of financial crises would increase. Therefore, in shed of light on this issue, this paper has employed the VECM model and two stages regression of unanticipated money supply to investigate the stance of neutrality of money supply in Malaysia. The findings may use to inference the exchange rate policy that implemented in Malaysia. Furthermore, this paper provides empirical evidence on the behaviour of money supply in developing country that support non-neutralist view. VECM models that employed by number of scholars (Husain and Mahmood, Mustafa, Thabet) [19-21] has been employed in the paper to examine the long run neutrality stance of money supply. Moreoever, Granger Causality test has taken places to analyze the relationship between variables in order to give a better picture in case of Malaysia. For the alternate specificiation, two stage regression model method in Maskay [22] has been used to examine the short run stance of money supply via the unanticipated money supply. Finally, the diagnostic tests have been run to examine the stabililty of the models.

Various sections are divided into following parts. Section 4 provides the literature review on the mentioned issues. Section 5 discusses the methodology that employed in the paper. Section 6 reports the empirical finding. Section 7 concludes the implication of the findings in the paper.

\section{Literature Review}

Mollo, Silva, and Torrance [4] provided a conceptual paper regarding the exchange rate regime from the perspective of money view. The neutrality of money has a long history of debate amongts the scholar. Classical economic theory is the ground for the Keynesian theorists to support the concept that, money has no infleuece towards economic permenantly but price level. Other real factors, for instance, advancement of technology and convergence of international trade are the reason to alter the economic growth. Friedman [8] is the pioneer who appreciates the price mechanism as the efficient tool to determine price equilibrium. Floating exchange rate regime, according to Friedman, poses high stability to restore the exchange rate equilibrium in the market. Later, McKinnon proposed fixed exchange rate regime should be more suitbale under the neutralists believe. Furthermore, monetarists who reject to treat money as neutral neither in long run nor short run, advocates that, fixed but adjustable exchange rate regime is a better solution. Discretionay adjustment is proposed by the Guttmann [23] and Kuttner [24], is vital towards the economic system. Since the market is 'blind', authorities have to employ dicretionary monetary policy to remove the obstacles that hinder the macroeconomic objectives. At the middle ground, neutralists that make a stance on the classical economic, advocates the short term changes which altered by the money fluctuation is due to the unanticipated money supply and market failure. Thus, money is non-neutral at the short term, named unanticipated money supply. However, in the long run, the prices would eventually restore to reflect the full anticipated from the market. Krugman [15] suggested, floating exchange rate regime with minimal government operation is suitable under this category. It is because, this group of theorists believe price mechanism is efficient to determine exchange rate in the long run. Therefore, minimm adjustement is needed to accommodate short term changes only.

At the theoritical ground, many models have been built up to accommodate the impact of anticipated money supply and unanticipated money supply towards real economic. Cooley and Hansen [25] employed real business cycel model with a cash-in-advance constraint money system. In Cooley and Hansen model, information imperfection has been assumed to accommodate the unanticipated money supply, thus, households have limited or no ability to inference market while money fluctuation is presented. Furthremore, households cannot observe the shocks in the model, therefore, inccurate decisions could be made. Although, Cooley and Hansen found strong evidence of the correlation between money supply and real output, however, the model has failed to explain the relationship between these variabes. Fisher and Seater [26] employed ARIMA model to develop a method on testing money neutrality and superneutrality position based on the long run derivative, LRD. All the tested variables are set into log-transform and free from unit root at $\mathrm{k}$ order. The $\mathrm{k}$ order integration for real output and money supply are important to determine the whether the money supply is hold under neutrality or superneutrality. Superneutrality posiotion hold when the $\mathrm{k}$ order integration of money supply is greater than the integrationorder of real output for one $(k+1)$. At this moment, the changes of real output would be regreessed into the changes of money supply because the permenant changes could be found from these variables. If the order of both variables are one, then the method would be able to test the long run elasticity of money supply towards real output. Fisher and Seater [26] claimed that, cointegration test is unnecessary in this method, it is because this method on how changes of money supply influence the other variables' growth rate. If any of the variables pose zero order of integration, the long run derivative can not be tested and neither long run neutrality nor long run superneutrality hold in the test.

King and Watson [27] also provided another approach to examine the neutrality position of money supply. Bivariate VAR model of order $\mathrm{p}$, for money supply neutrality position, is proposed as below: 


$$
\begin{aligned}
& \Delta y_{t}=\lambda_{y m} \Delta m_{t}+\sum_{j=1}^{p} \alpha_{j, y y} \Delta y_{t-j}+\sum_{j=1}^{p} \alpha_{j, y m} \Delta m_{t-j}+\epsilon_{t}^{\eta} \\
& \Delta m_{t}=\lambda_{m y} \Delta y_{t}+\sum_{j=1}^{p} \alpha_{j, m y} \Delta y_{t-j}+\sum_{j=1}^{p} \alpha_{j, m m} \Delta m_{t-j}+\epsilon_{t}^{m}
\end{aligned}
$$

$\Delta \mathrm{y}_{\mathrm{t}}$ and $\mathrm{m}_{\mathrm{t}}$ are represent the changes of output and money supply at time $t, \lambda_{\mathrm{ym}}$ captures the contemporanous effect of money supply towards real output, $\lambda_{\text {ym }}$ captures the effect of real output towards real output, $\epsilon_{t}^{\eta}$ is vector of shocks from other variables than money supply, and $\epsilon_{t}^{m}$ is the exogenous shock of money. However, for the long run superneutrality of money supply, the equation (1) can be extended into the following equation:

$$
\Delta m_{t}-\gamma_{m y} \Delta y_{t}=\beta_{m m}\left(\Delta m_{t-1}-\gamma_{m y} \Delta y_{t}\right)+\sum_{j=0}^{p-1} \sim j \alpha_{m y} \Delta_{y_{t-j}}^{2}+\sum_{j=0}^{p-1} \sim j \alpha_{m m} \Delta_{m_{t}-j}^{2}+\epsilon_{t}^{m}
$$

King and Watson (1997) poses two assumption which are, covariance of $\epsilon_{t}^{\eta}$ and $\epsilon_{t}^{m}$ have to be equal to zero and one out of the following coefficients $\left(\lambda_{\mathrm{ym}}, \lambda_{\mathrm{my}}, \gamma_{\mathrm{my}}\right.$ and $\left.\gamma_{\mathrm{ym}}\right)$ must be known or set to zero

Empirically, Sulku [28] employed ARIMA model which proposed by Fisher and Seater to examine the long run money supply neutrality position of Turkey. Sulku found long run neutrality of money is hold in the Turkey from 1987:Q1 to 2006:Q3. However, there is no evidence to show that long run superneutrality of money is hold under same period. Serletis and Koustas [29] emoloyed King \& Watson method to test the money supply neutraltify position for 10 selected developed countries $^{1}$. The results have revealed that 2 out of 10 countries do not have permenant random walk shocks in the money supply where these two country has an integration of zero. However, the rest of the countries have singificant evidence to confirm that money supply is neutral in long run twoards the real output. Herwartz and Reimers [30] used data from 110 countries to examine the relationship between output and money. Herwartz and Reimers claimed that, money aggretation has contributed to the economic of a nation in the pooled level. Furthermore, El-Seoud [31] found that, money is neutral in both long run and short run in Bahrain which supported the Keynesian's theory and real business cycle. Later, Hasan also sought the similar finding as Sulku with VAR model in the Indian market. Hasan further claime that, monetary aggretates and pirces has feedback relatinoship in India market, therefore, monetary aggregates is considered as an weak instrument for nominal targeting. Mustafa, Ahmed \& Siddiqui [21] and Husain and Mahmood [19], who employed ECM model to examine the influences of money supply towards prices and real economic in Pakistan. Mustafa, et al. [21] sought that, money supply, M2 has unidirectional causal effect towards prices in Pakistan in the short run only. But Husain and Mahmood found that, M2 has affected stock market in both long run and short run, but M1 has no influences in both long run and short run. Thus, money supply does not effectively influence stock market in Pakistan. The above studies are focused in one country only, however, Thabet took a step ahead to examine the influences of one country (United States) towards anohter country (Canada) stock market via the ECM model with long run structural modelling technique. Thabet found that, United States money supply, M2 posed statistically significant influence towards Canada stock market in long run. In the case of Malaysia, moey aggregation has bidirectional causality effect between monetary aggregation, prices and output [32]. This findings have provided supports towards Keynesian's theory. Furthermore, Habibullah, et al. [33] also provides similar findings where the money is neutral towards ouput in Malaysia.
However, Bilquees, Mukhtar \& Sohail [34] has reported that, nonneutrality of money has stronger evidence than Keynesian theory in Pakistan in long run. In short run, Keynesian's theory is hold. Thus, Bilquees, el al. claimed that, due to the bi-directional causality between money supply and prices, thus, inflation is not efficient to become the nominal anchor for Pakistan macroeconomic. Furthermore, Arintoko [35] has employed Fisher and Seater method to examine the long run neutrality of money supply and inflaiton in Indonesia. Arintoko claimed that, there is limited evidence to support the long run neutrality hold in Indonesia for M1 and M2. Particulary, monetary aggregation in Indonesia has statistically significant positive effect towards Indonesian real economic in long run.

For the study that dichotonomized money supply into anticipated and unancicipated found mixed results. Falk [36], as the Keynesians, examined the influence of unanticipated money supply towards the build forsales, single-family housing price. Based on the Barry and Rush model, Falk employed the measurement technique to obtain the serie of unanticiaped money supply data from 1964:Q1 to 1977:Q4 in the United States market. Empirical evidence showed that, influence of unanticipated money supply in short run does alter the housing price, which is in line with the neutralists' efficient market hypothesis. Anticipated money supply, as expected, change no macroeconomic variables but price level. However, Maskay claimed that, anticipated money supply had more significant towards stock market in United States from 1959:Q1 to 2006:Q2. Ghazali and Wong [37] findings supported the rational expectation of theory that unanticipated money supply assert more changes towards stock return movement in developoing market, Malaysia. Thus, Ghazali and Wong claimed that, long run neutrality of money supply is hold in Malaysian stock market. Later, Thornton and Molyneux [38] examined the anticipated and unanticipated money supply that influence towards the income velocity. Empirical results showed different evidence from Falk findings. The Granger causality test showed that, neither anticipated nor unanticipated money supply is statistically significant to explain the income velocity in United Kingdom. Thus, Thornton and Molyneux suggested the existence of other real macroeconomic variables that could influence the income velocity.

\section{Methodology}

Based on the Quantity Theory of Money, the increment of money supply has the influence of towards nominal price level rather than real output. Therefore,

$$
\mathrm{M}_{\mathrm{t}} \mathrm{V}_{\mathrm{t}}=\mathrm{P}_{\mathrm{t}} \mathrm{Y}_{\mathrm{t}}
$$

Where, $M_{t}$ is the monetary aggregation at time $t, V_{t}$ is the velocity of money at time $t, \mathrm{P}_{t}$ is the price level at time $t$, and $\mathrm{Y}_{t}$ is the real output. Then, the equation (6) can be rewrite in the following term:

$$
M_{t}=\frac{Y_{t}}{V_{t}} P_{t}=k P_{t}
$$

Where, $k=\frac{Y_{t}}{V_{t}}$. Therefore, it is a straight forward to examine the influence of monetary supply towards the real output.

Using the data from 1996:Q1 to 2014:Q4, this paper employed the vector error correction model to examine the money neutrality stance in Malaysia. All the data are obtained from various version of Quarterly Bulletin, Bank Negara Malaysia and International Monetary Fund's eLibrary data bank. Monetary supply, M1, M2 and M3 are employed as the independent variables, real GDP of Malaysia is used as dependent 
variables. However, total domestic credit to non-financial sector, real effective exchange rate and government expenditure are used as the control variables. Sulku employed M1, M2, M3 and M2Y into the study to test the money neutrality in Turkey. The M2Y is defined as the total M2 plus the foreign exchange deposits. However, in this study M2Y is not needed because, M2 is, based on the definition of Bank Negara Malaysia, summation of M1, saving deposits, fixed deposits, NIDs, repos and foreign currency deposits. In order to obtain unanticipated money supply, several methods have been proposed. Based on LucasSargent-Wallace proposition, unanticipated money supply is the residuals of the ordinary least square estimation with lagged values of the money supply itself. This method has been employed by numbers of scholars including Falk and Thornton and Molyneux.

$$
\mathrm{m}_{\mathrm{t}}=\alpha+\beta_{1} \mathrm{~m}_{\mathrm{t}-1}+\beta_{2} \mathrm{~m}_{\mathrm{t}-2}+\beta_{3} \mathrm{~m}_{\mathrm{t}-3}+\varepsilon_{\mathrm{t}} \mathrm{m}_{\mathrm{t}}
$$

Where, $\mathrm{m}_{\mathrm{t}}$, the money supply at time $\mathrm{t}$, is regressed into its lagged values, and $\varepsilon_{\mathrm{t}}$ is the unanticipated money supply at time t. However, Maskay employed two stage regression models to estimate the unanticipated money supply in the study. First, the difference of money supply is regressed with its past value and the expected government expenditure as following:

$$
\Delta \mathrm{m}_{\mathrm{t}}=\alpha+\beta_{1} \Delta \mathrm{m}_{\mathrm{t}-1}+\beta_{2} \Delta \mathrm{m}_{\mathrm{t}-2}+\beta_{3} \Delta \mathrm{m}_{\mathrm{t}-3}+\beta_{4} \Delta \mathrm{m}_{\mathrm{t}-4}+\beta_{5} \operatorname{Fexp}_{\mathrm{t}}+\varepsilon_{\mathrm{t}}
$$

Where, $\Delta \mathrm{m}_{\mathrm{t}}$ is the first difference of money supply at time $t$, Fexp is the expected government expenditure at time, $t$ and $\varepsilon_{t}$ is the residual of the regression. Furthermore, $\left.\exp _{\text {.t-1 }}\right)$ )

$\operatorname{Fexp}_{\mathrm{t}=} \log \left(\right.$ real $\left.\exp _{\mathrm{t}}\right)-0.2\left(\log \left(\right.\right.$ actual $\left.\left.\exp _{\mathrm{t}}\right)\right)+0.8(\log (\operatorname{expected}$

Where, real $\exp _{t}$ refers to the real government expenditure at time $t$, actual exp is the actual government expenditure at time $t$, and expected $\exp _{\text {tt- } 1}$ is the lagged value of expected government expenditure at time t. The 2:8 ratio towards the expected government expenditure is obtained from Maskay. Later, the predicted value from equation (6) is employed to calculate the unaniticpated money supply based on the following formula:

$$
\Delta \mathrm{ums}_{\mathrm{t}}=\Delta \mathrm{m}_{\mathrm{t}}-\mathrm{n}_{\mathrm{t}}
$$

Where, $\Delta u_{m}$ is referring to the unanticipated change in money supply at time, $t, \Delta \mathrm{m}_{\mathrm{t}}$ is the changes of money supply at time, $t$, and $n_{t}$ is the predicted money supply from equation (6).

At the second stage, the unanticipated change of money supply is regressed into the following model:

$$
\mathrm{Y}_{\text {real,t }}=\alpha+\beta_{1} \Delta \mathrm{ums}_{\mathrm{t}}+\beta 2 \Delta \mathrm{m}_{\mathrm{t}}+\beta 3 \operatorname{lgreer}_{\mathrm{t}}+\beta_{4} \operatorname{lgprcdt}_{\mathrm{t}}+\varepsilon_{\mathrm{t}}
$$

where, $\mathrm{Y}_{\text {real, }}$ is the real GDP at time $\mathrm{t}, \Delta \mathrm{ums}_{\mathrm{t}}$ is referring to the unanticipated change in money supply at time, $t, \Delta \mathrm{m}_{t}$ is the changes of money supply at time $t$, lgreer $r_{t}$ is the real effective exchange rate in $\log$ form at time $t$, lgprcdt $t_{t}$ and $\varepsilon_{t}$ is the residual of the regression. In this study, the two stage regression model is employed to examine the influence of unanticipated money supply as the alternative specification.

The strategy to examine the neutrality of money has been set up. First, descriptive analysis has been carried out and followed by the unit root test to examine the stationary position of variables. Furthermore, two cointegration test which are Johansen cointegration test and EngleGranger two steps method have been conducted to examine the long run relationship between real output and monetary supply, M1, M2 and M3. Finally, monetary supply, M1, M2 and M3 have been tested separately in the different VECM model in order to examine the long run relationship found from the cointegration tests. Finally, a series of diagnostic tests have been employed to detect the possible issues that rise up from the non-normality distributed residuals, heteroskedasticity and serial correlation. Since in 1997 to 1998, Malaysia faced with serious financial crises, therefore, time dummy of financial crises has been accommodate into the model. For the alternative specification, the above mentioned two stage regression model for the unanticipated money supply would be taking place to validate the short run changes of money supply towards real output, if any.

\section{Empirical Analysis}

\section{Main specification}

The descriptive analysis is shown in the following Table 1.

At the first glance, all variables are rejecting null hypothesis of Jarque-Bera test besides dependent variable, real GDP. Thus, $\log$ transformation has been needed as the remedy to the JarqueBera test. Next, unit root test has been carried out. Dickey FullerGeneralized Least Square (DF-GLS) developed by Elliot, Rothenberg and Stock [39] have been employed in the study. DF-GLS provides more power towards small size sample. As the complimentary of DFGLS, Augmented Dickey Fuller (ADF) test has been carried out. The results are reported into two tables, which are Table 2 (for the Dickey Fuller-Generalized Least Square test, DF-GLS) and Table 3 (for the Augmented Dickey Fuller test, ADF). All the lag lengths in the tests obtained from the Akaike Information Criteria (AIC). Based on the Table 2, all variables besides lgrgdp (log form of real GDP), lgprcdt (log form of domestic credit), lgums1 (log form of unanticipated money supply of M1), lgums3 ( $\log$ form of unanticipated money supply of M3) cannot reject the hypothesis of unit root at 10 percent level. However,

\begin{tabular}{|l|c|c|c|c|c|c|}
\hline & M1 & M2 & M3 & RGDP & EXPEN & PRCDT \\
\hline Mean & $4.43 \mathrm{E}+10$ & $2.09 \mathrm{E}+11$ & $2.28 \mathrm{E}+11$ & $3.15 \mathrm{E}+10$ & $1.10 \mathrm{E}+10$ \\
\hline Median & $3.10 \mathrm{E}+10$ & $1.57 \mathrm{E}+11$ & $1.73 \mathrm{E}+11$ & $3.11 \mathrm{E}+10$ & $9.05 \mathrm{E}+09$ \\
\hline Maximum & $1.03 \mathrm{E}+11$ & $4.67 \mathrm{E}+11$ & $4.71 \mathrm{E}+11$ & $5.18 \mathrm{E}+10$ & $2.58 \mathrm{E}+10$ & $4.66 \mathrm{E}+11$ \\
\hline Minimum & $1.28 \mathrm{E}+10$ & $7.05 \mathrm{E}+10$ & $9.56 \mathrm{E}+10$ & $1.48 \mathrm{E}+10$ & $2.44 \mathrm{E}+09$ & $1.15 \mathrm{E}+11$ \\
\hline Std. Dev. & $2.86 \mathrm{E}+10$ & $1.33 \mathrm{E}+11$ & $1.23 \mathrm{E}+11$ & $1.14 \mathrm{E}+10$ & $6.27 \mathrm{E}+09$ & $9.78 \mathrm{E}+10$ \\
\hline Skewness & 0.825731 & 0.700666 & 0.761951 & 0.186505 & 0.51516 & 0.886635 \\
\hline Kurtosis & 2.285886 & 2.01578 & 2.108872 & 1.93134 & 2.00252 & 2.376753 \\
\hline Jarque-Bera & 10.2514 & 9.285993 & 9.868551 & 4.05704 & 6.512331 & 11.18758 \\
\hline Probability & 0.005942 & 0.009629 & 0.007196 & 0.13153 & 0.038536 & 0.003721 \\
\hline Sum & $3.36 \mathrm{E}+12$ & $1.59 \mathrm{E}+13$ & $1.73 \mathrm{E}+13$ & $2.39 \mathrm{E}+12$ & $8.34 \mathrm{E}+11$ & $1.63 \mathrm{E}+13$ \\
\hline Sum Sq. Dev. & $6.13 \mathrm{E}+22$ & $1.33 \mathrm{E}+24$ & $1.14 \mathrm{E}+24$ & $9.75 \mathrm{E}+21$ & $2.95 \mathrm{E}+21$ & $7.17 \mathrm{E}+23$ \\
\hline Observations & 76 & 76 & 76 & 76 & 76 \\
\hline
\end{tabular}

Table 1: Descriptive Analysis of Variables. 


\begin{tabular}{|c|c|c|c|c|}
\hline \multirow[b]{2}{*}{ Variables } & \multicolumn{2}{|r|}{ Level } & \multicolumn{2}{|c|}{ First Difference } \\
\hline & Constant & Constant, Trend & Constant & Constant, Trend \\
\hline Igrgdp & $-0.5255(2)$ & $-2.1085(2)$ & $-1.1621(4)$ & $-2.5510(4)$ \\
\hline $\operatorname{lgm} 1$ & $0.8872(5)$ & $-1.5423(5)$ & $-4.2749^{+* * *}(4)$ & $-4.4227^{* * *}(5)$ \\
\hline Igm2 & $1.1175(4)$ & $-1.7589(1)$ & $-5.0286^{+* * *}(0)$ & $-5.0615^{* * * *}(0)$ \\
\hline $\operatorname{lgm} 3$ & $1.2124(4)$ & $-1.8085(1)$ & $-5.1405^{* * * *}(0)$ & $-5.2337^{* * *}(0)$ \\
\hline Igreer & $-0.9459(0)$ & $-1.5069(0)$ & $-2.8866^{* * * *}(3)$ & $-5.6709^{* * *}(0)$ \\
\hline Igprcdt & $1.5090(3)$ & $-1.0697(0)$ & -7.4256 & $-2.2973(6)$ \\
\hline Igexp & $0.3123(6)$ & $-3.6126^{* *}(6)$ & $-1.2178(5)$ & $-2.2487(5)$ \\
\hline Igums1 & $-1.1630(3)$ & $-2.5758(3)$ & $-0.1663(10)$ & $-1.2853(10)$ \\
\hline Igums2 & $-7.1690^{+* * *}(0)$ & $-7.7030^{* * * *}(0)$ & $-10.9153^{* * *}(1)$ & $-9.7945^{* * *}(1)$ \\
\hline Igums3 & $-2.8705^{* * * *}(2)$ & $-3.1222^{* *}(2)$ & $-1.1874(7)$ & $-2.0897(7)$ \\
\hline
\end{tabular}

*10 percent significant level, "*5 percent significant level, ${ }^{* * *} 1$ percent significant level. Lagged length based on AIC are reported in the parenthesis.

Table 2: Result of Unit Root Test (DF-GLS).

\begin{tabular}{|c|c|c|c|c|}
\hline \multirow[b]{2}{*}{ Variables } & \multicolumn{2}{|c|}{ Level } & \multicolumn{2}{|c|}{ First Difference } \\
\hline & Constant & Constant, Trend & Constant & Constant, Trend \\
\hline Igrgdp & $-0.6579(3)$ & $-4.1981(5)$ & $-7.2813^{* * * *}(2)$ & $-7.2451^{* * *}(2)$ \\
\hline $\operatorname{lgm} 1$ & $0.5896(6)$ & $-5.5027^{+* * *}(7)$ & $-4.2399^{* * *}(5)$ & $-4.6080^{+* * *}(4)$ \\
\hline $\operatorname{lgm} 2$ & 0.1038 (1) & $-2.6355(1)$ & $-5.1768^{* * * *}(0)$ & $-5,2187^{+* *+}(0)$ \\
\hline $\operatorname{lgm} 3$ & $-0.1564(1)$ & $-2.7130(1)$ & $-5.4111^{\cdots * *}(0)$ & $-5.4921^{* * *}(0)$ \\
\hline Igreer & $-2.6308(0)$ & $-2.2734(0)$ & $-6.1168^{* * * *}(0)$ & $-6.2456^{+*+*}(0)$ \\
\hline Igprcdt & $0.7167(0)$ & 0 & $-6.0341^{* * *}(0)$ & $-6.1501^{* * t}(0)$ \\
\hline Igexp & $-0.1256(4)$ & $-2.9425(8)$ & $-4.8766^{* * *}(3)$ & $-23.8366^{* * *}(2)$ \\
\hline Igums1 & $-3.1623^{* *}(3)$ & $-3.4971^{* *}(3)$ & $-9.9056^{* * \prime \prime}(2)$ & $-9.8675^{*+*}(2)$ \\
\hline Igums2 & $-7.1401^{+* * *}(0)$ & $-7.6794^{*+* *}(0)$ & $-4.2979^{\prime * \prime \prime}(11)$ & $-4.3153^{+* *}(11)$ \\
\hline Igums3 & -5.7412 & -6.498 & $-9.0806 \cdots(2)$ & $-9.0171^{+* *}(2)$ \\
\hline
\end{tabular}

"10 percent significant level, "*5 percent significant level, ${ }^{* *+} 1$ percent significan level. Lagged length based on AIC are reported in the parenthesis.

Table 3: Result of Unit Root Test (ADF).

\begin{tabular}{|l|c|c|c|c|c|c|}
\hline \multirow{2}{*}{} & \multicolumn{2}{|c|}{ EigenValue } & \multicolumn{2}{c|}{ Trace Statistic } & \multicolumn{2}{c|}{ Max Eigen } \\
\cline { 2 - 7 } & $r=0$ & $r \leq 0$ & $r=0$ & $r \leq 0$ & $r=0$ & $r \leq 0$ \\
\hline Igm1 & $0.5411^{*+*}$ & 0.0134 & 54.6767 & 0.9338 & 53.7428 & 0.9338 \\
\hline $\operatorname{lgm} 2$ & $0.4898^{*+*}$ & 0.0146 & 49.5163 & 1.061 & 48.4553 & 1.061 \\
\hline $\operatorname{lgm} 3$ & $0.3507^{*+*}$ & 0.1189 & 40.2155 & 9.1215 & 31.0941 & 9.1215 \\
\hline
\end{tabular}

"10 percent significant level, "*5 percent significant level, "*1 percent significan level.

Table 4: Result of Johansen Cointegration Test.

in Augmented Dickey Fuller test (ADF), none of the variable cannot reject the null hypothesis of unit root at first difference. Therefore, all the variables are considered stationary at the first differences, except lgums 2 under the ADF test, where lgums2 reject the null hypothesis of ADF test at level.

In order to test the long run cointegration between variables, two cointegration tests have been carried out, which is Johansen cointegration test and Engle-Granger cointegration test. EngleGranger cointegration test involves two steps method. First, the desired testing variables are regressed in the ordinary least square model in order to obtain its residual. Then, the residual has been tested through the unit root test, Augmented Dickey Fuller test (ADF). T-statistic from the ADF test is compared with the critical value of McKinnon for large sample or Charemza and Blangiewicz [40] for small sample. The rejection of null hypothesis under the ADF test implies the existence of long run cointegration between the variables. Finally, the residuals from stage one has been employed into the Error Correction Model to validate the long run relationship of the variables. The result of EngleGranger cointegration test has been returned in the Table 5 and Table 6 . However, the result of Johansen cointegration test is straight forward and it has been reported as in the Table 4 .

Based on the result of Johansen cointegration test and EngleGranger cointegration test, it is clear that, monetary supply, M1, M2 and M3 has long run association with real output. The Johansen cointegration test has revealed that at most 1 cointegration equation has been found. The result is consistent with the findings from Engle Granger two step method cointegration test, where the residuals from the inverted regression which is not showing in the Table 5 has failed to reject the unit root hypothesis ${ }^{3}$. Thus, the cointegration test has found that the model is a long run model and suitable to proceed with Vector Error Correction Model (VECM). Furthermore, the result from Error Correction Model also confirmed the long run relationship between money supply, M1, M2, M3 and real output in each model, where the error correction terms from each model are statistically significant with

\begin{tabular}{|c|c|c|}
\hline \multirow{2}{*}{} & \multicolumn{2}{|c|}{ Level } \\
\cline { 2 - 3 } & Constant & Constant, Trend \\
\hline $\operatorname{lgm} 1$ & $-3.2952^{* *}$ & $-3.2513^{* *}$ \\
\hline $\operatorname{lgm} 2$ & $-3.1771^{* *}$ & $-3.1579^{* *}$ \\
\hline $\operatorname{lgm} 3$ & $-2.9633^{* *}$ & $-2.9340^{*+}$ \\
\hline
\end{tabular}

*10 percent significant level, ${ }^{* *} 5$ percent significant level, ***1 percent significant level. Dependent Variable is real GDP in log transformation. Critical value compared with Charemza (1990) small sample cointegration critical value.

Table 5: Unit Root Test on the Residuals of First Stage Engle-Granger Cointegration test.

\begin{tabular}{|c|c|c|c|c|c|}
\hline \multicolumn{2}{|l|}{ Model 1 (M1) } & \multicolumn{2}{|l|}{ Model 2 (M2) } & \multicolumn{2}{|l|}{ Model 3 (M3) } \\
\hline \multirow[t]{2}{*}{ C } & 0.0042 & \multirow[t]{2}{*}{ C } & -0.0322 & \multirow[t]{2}{*}{ C } & -0.0161 \\
\hline & -0.1954 & & $(-1.2626)$ & & $(-0.6695)$ \\
\hline \multirow[t]{2}{*}{$\Delta(\operatorname{lgm} 1(-1))$} & 0 & \multirow[t]{2}{*}{$\Delta(\operatorname{lgm} 2(-1))$} & $0.9413^{\star}$ & \multirow[t]{2}{*}{$\Delta(\operatorname{lgm} 3(-1))$} & 0.74 \\
\hline & $(-0.0924)$ & & -1.7643 & & -1.39 \\
\hline \multirow[t]{2}{*}{$\Delta(\operatorname{lgm} 1(-2))$} & $1.1018^{* * *}$ & \multirow[t]{2}{*}{$\Delta(\operatorname{lgm} 2(-2))$} & $1.1948^{* *}$ & \multirow[t]{2}{*}{$\Delta(\operatorname{lgm} 3(-2))$} & $1.3091^{* *}$ \\
\hline & -3.0155 & & -2.0553 & & -2.2711 \\
\hline \multirow{2}{*}{$\Delta(\operatorname{lgm} 1(-3))$} & 0.4329 & \multirow[t]{2}{*}{$\Delta(\operatorname{lgm} 2(-3))$} & 0.531 & \multirow{2}{*}{$\Delta(\operatorname{lgm} 3(-3))$} & 0.6221 \\
\hline & -1.1744 & & -0.9055 & & -1.0569 \\
\hline \multirow[t]{2}{*}{$\Delta(\operatorname{lgm} 1(-4))$} & -0.2551 & \multirow[t]{2}{*}{$\Delta(\operatorname{lgm} 2(-4))$} & -0.0456 & \multirow[t]{2}{*}{$\Delta(\operatorname{lgm} 3(-4))$} & -0.183 \\
\hline & $(-0.6821)$ & & $(-0.0823)$ & & $(-0.3253)$ \\
\hline \multirow[t]{2}{*}{$\Delta(\operatorname{lgrgdp}(-1))$} & $-0.4484^{* *}$ & \multirow[t]{2}{*}{$\Delta(\operatorname{lgrgdp}(-1))$} & $-0.4746^{* *}$ & \multirow[t]{2}{*}{$\Delta(\operatorname{lgrgdp}(-1))$} & $-0.5259^{* * *}$ \\
\hline & $(-2.1957)$ & & $(-2.3289)$ & & $(-2.7260)$ \\
\hline \multirow[t]{2}{*}{$\Delta(\operatorname{lgrgdp}(-2))$} & $-0.4426^{* *}$ & \multirow[t]{2}{*}{$\Delta(\operatorname{lgrgdp}(-2))$} & $-0.4808^{\star *}$ & \multirow[t]{2}{*}{$\Delta(\operatorname{lgrgdp}(-2))$} & $-0.4907^{\star *}$ \\
\hline & $(-2.2519)$ & & $(-2.4660)$ & & $(-2.5698)$ \\
\hline \multirow[t]{2}{*}{$\Delta(\operatorname{lgrgdp}(-3))$} & -0.1237 & \multirow[t]{2}{*}{$\Delta(\operatorname{lgrgdp}(-3))$} & -0.1553 & \multirow[t]{2}{*}{$\Delta(\operatorname{lgrgdp}(-3))$} & -0.1365 \\
\hline & $(-0.7466)$ & & $(-0.9291)$ & & $(-0.8198)$ \\
\hline \multirow[t]{2}{*}{$\Delta(\operatorname{lgrgdp}(-4))$} & -0.0446 & \multirow[t]{2}{*}{$\Delta(\operatorname{lgrgdp}(-4))$} & -0.0164 & \multirow[t]{2}{*}{$\Delta(\operatorname{lgrgdp}(-4))$} & -0.0068 \\
\hline & $(-0.3726)$ & & $(-0.1367)$ & & $(-0.0563)$ \\
\hline \multirow{2}{*}{$\begin{array}{l}\text { Error } \\
\text { Correction } \\
\text { Term }\end{array}$} & $-0.5563^{* *}$ & \multirow{2}{*}{$\begin{array}{l}\text { Error } \\
\text { Correction } \\
\text { Term }\end{array}$} & $-0.5802^{* \star *}$ & \multirow{2}{*}{$\begin{array}{l}\text { Error } \\
\text { Correction } \\
\text { Term }\end{array}$} & $-0.4904^{\star *}$ \\
\hline & $(-2.6367)$ & & $(-2.7440)$ & & $(-2.5323)$ \\
\hline $\mathrm{R}^{2}$ & 0.5898 & $\mathrm{R}^{2}$ & 0.5904 & $\mathrm{R}^{2}$ & 0.5751 \\
\hline Adj. $R^{2}$ & 0.5293 & Adj. $R^{2}$ & 0.5299 & Adj. $\mathrm{R}^{2}$ & 0.5124 \\
\hline $\begin{array}{l}\text { Durbin- } \\
\text { Watson }\end{array}$ & 1.9317 & Durbin-Watson & 1.9359 & $\begin{array}{l}\text { Durbin- } \\
\text { Watson }\end{array}$ & 1.9468 \\
\hline
\end{tabular}

*10 percent significant level, ${ }^{* *} 5$ percent significant level, ${ }^{* * *} 1$ percent significant level. Dependent Variable is real GDP in log transformation. T-statistic is reported in the parenthesis.

Table 6: Result of Engle-Granger Two Steps Cointegration test Error Correction Model. 
a negative coefficient. However, for the short run estimation, lagged two period value in each model are statistically significant towards the real output. On the other hand, the short run relationship is found in each model between money supply and real output. Therefore, at the next step, Granger causality test and VECM have been carried out to further examine the relationship between money supply and real output. Table 7 reports the result from VECM based on different model however, Table 8 reports the result from Granger Causality test [41-44].

According to the result in Table 7, cointegration equation in both M1 and M2 model has significant impact towards the real output in the long run but not in the M3 model. Furthermore, the growth rate of M1 and M2 in short run poses significant influence towards the real output. Although the influence of growth rate of M3 is not statistically significant, but, the Wald test in the M3 model has been statistically rejected the null hypothesis, where the joint coefficient has no impact towards real output, at the 1 percent significant level. For the exogenous variables, real effective exchange rate and domestic private credit cannot reject the null hypothesis at any significant level except the domestic private credit in M1 model. This has implied that, the changes of money supply has the influences towards the changes of real output. The findings have confronted the stance where money supply is neutral in Malaysia. Furthermore, based on the result from Granger Causality test, money supply, M1, M2 and M3 has unidirectional relationship with real output without feedback. All unidirectional relationships to real output are statistically significant [45]. Therefore, money supply in Malaysia has violated the Keynesian's view of Quantity Theory of Money. Money is not neutral in both short run and long run in Malaysia. Additional, there are only two cases have bi-directional relationship which are, M2 and M3, and M2 and domestic private credit.

\begin{tabular}{|c|c|c|c|}
\hline Model & M1 Model & M2 Model & M3 Model \\
\hline Cointegration Equation & $\begin{array}{c}-1.0054^{\star \star \star} \\
(-8.4995)\end{array}$ & $\begin{array}{c}-0.9689^{\star \star \star} \\
(-7.9937)\end{array}$ & $\begin{array}{c}0.0025 \\
-0.3418\end{array}$ \\
\hline \multirow[t]{2}{*}{$\Delta \operatorname{lgm} 1$} & $-1.1240^{\star * \star}$ & & \\
\hline & $(-2.9698)$ & & \\
\hline \multirow[t]{2}{*}{$\Delta \operatorname{lgm} 2$} & & $1.2347^{* *}$ & \\
\hline & & -2.4494 & \\
\hline \multirow[t]{2}{*}{$\Delta \operatorname{lgm} 2$} & & & 0.8791 \\
\hline & & & -1.4787 \\
\hline \multirow[t]{2}{*}{$\Delta$ lgreer } & -1.3427 & -0.77599 & -0.0966 \\
\hline & $(-1.2596)$ & $(-0.7155)$ & $(-0.0884)$ \\
\hline \multirow[t]{2}{*}{$\Delta$ lgprcdt } & $2.1510^{*}$ & 1.1254 & 0.1195 \\
\hline & -1.9644 & -1.0106 & -0.0994 \\
\hline \multirow[t]{2}{*}{ Time dummy } & -0.006 & 0.0398 & 0.0024 \\
\hline & $(-0.0816)$ & -0.8812 & -0.0531 \\
\hline
\end{tabular}

*10 percent significant level, ${ }^{* *} 5$ percent significant level, ${ }^{* *} 1$ percent significant level. Dependent Variable is growth rate of real GDP in log transformation. T-statistic is reported in the parenthesis.

Table 7: Result from VECM test.

\begin{tabular}{|c|c|c|c|c|c|c|}
\hline & Igrgdp & $\lg 11$ & $\operatorname{lgm} 2$ & $\operatorname{Igm} 3$ & Igreer & Igpredt \\
\hline Igrgdp & & $15.4431^{\star \star *}$ & $17.8647^{*+*}$ & $14.5750^{* * *}$ & $6.6218^{* * t}$ & $10.6000^{* * *+}$ \\
\hline $\operatorname{lgm} 1$ & 0.1731 & & $4.5287^{\star *}$ & $3.5593^{* *}$ & $7.4348^{* * t}$ & 1.0592 \\
\hline Igm2 & 0.1636 & 0.8229 & & $3.1204^{*}$ & $4.6447^{* *}$ & $3.3001^{* *}$ \\
\hline $\operatorname{lgm} 3$ & 0.2106 & 0.1889 & $3.5378^{* *}$ & & $3.4508^{* *}$ & 2.1231 \\
\hline Igreer & 0.9826 & 0.1362 & 0.0502 & 0.1017 & & 0.0698 \\
\hline Igprcdt & 0.4018 & $4.7958^{* *}$ & $4.5973^{* *}$ & $5.8000^{* * *}$ & 1.1691 & \\
\hline
\end{tabular}

*10 percent significant level, ${ }^{* *} 5$ percent significant level, ${ }^{* * *} 1$ percent significant level. Dependent Variable is real GDP in log transformation. All results are reported in F-statistic.

Table 8: Result from Granger Causality test.

\begin{tabular}{|l|c|c|c|c|}
\hline \multicolumn{2}{|c|}{ Serial Correlation LM test } & \multicolumn{2}{|c|}{ Normality Test } & ARCH LM Test \\
\hline & p-value & & p-value & p-value \\
\hline Model 1 (M1) & 0.9828 & 0.0773 & 0.962 & 0.0673 \\
\hline Model 2 (M2) & 0.9559 & 1.5847 & 0.4528 & 0 \\
\hline Model 3 (M3) & 0.2609 & 1.7237 & 0.4223 & 0.0759 \\
\hline
\end{tabular}

Table 9: Diagnostic Test on Residuals of VECM Models.

Next, the result of diagnostic tests is reported in the following Table 9. Based on the result in Table 9, VECM models do not have the serial correlation problem and the residuals are normally distributed. However, the ARCH LM test has revealed that, Model 2 has rejected the null hypothesis of ARCH LM test where there is no ARCH or structural break in the model. However, when Model 2 transform into differences, the problem has been solved. For the Model 1 and Model 3 , the null hypothesis cannot be rejected at 5 percent and 1 percent level. Moreover, the generalized impulse responses are reported in the appendix to illustrate the changes of variables when one standard deviation of shock occurs in the model. Therefore, the VECM models are considered fitted [46].

\section{Alternative specification}

Since M1 and M2 have short run effect towards real output, therefore it is reasonable to examine whether these impacts are caused by unanticipated money supply or not. This alternative specification has provided another stance to support the findings from VECM and Granger Causality. The estimated result from the OLS of unanticipated money supply towards the real output has been reported in the Table 10. The findings are reported into two categories where with or without the financial crisis time dummy.

At first glance, for each model, the F-statistic is significant at 1 percent level and both $\mathrm{R}^{2}$ and adjusted $\mathrm{R}^{2}$ have reached more than 70 percent. This implies the models are fitted well and the joint statistic of each independent variables are able to explain the changes of real output. While interpreting the influences of independent variables towards the real output, in all models, only the unanticipated money supply which derived from M2 is statistically significant to influence the real output. However, when the time dummy of financial crisis added into the model, the significant level has reduced. This implies that, in Malaysia case, unanticipated money supply poses more influence than anticipated money supply towards real output [47]. The findings have complimented the result of the main specification. Generally, the evidence to support the neutrality of money stance in Malaysia is limited. Moreover, for the control variables, real effective exchange rate is not able to reject the null hypothesis in the models. However, for the domestic credit, the increment of domestic private credit has statistically significant increased the real output.

\section{Implication and Conclusion}

Generally, based on the both specifications, there is little evidence to support the existence of neutrality of money supply stance in Malaysia no matter in long run or short run. Moreover, the short run influences are mostly due to the unanticipated money supply, especially in the model of M2 and M3. The findings are in line with the nonneutralists (Bilquees, Mukhtar, Sohail and Arintoko) where money is non-neutral at all time. Monetary aggregation has long run and short run causality relationship with real output. While taking a closer look from the Granger Causality test, money supply, M1, M2 and M3 has uni-directional causality relationship towards real output as in Figures 1-3. This implies that, money can be used as the nominal targeting to 
Citation: Sam YH, Geetha C, Chandran VV, Ahmed A (2015) Testing the Neutrality of Money towards Real Output: A Case of Malaysia. Int J Econ Manag Sci 4: 298. doi:10.4172/21626359.1000298

Page 7 of 9

\begin{tabular}{|c|c|c|c|c|c|c|}
\hline \multirow[b]{2}{*}{ Variables } & \multicolumn{2}{|c|}{ Model 1} & \multicolumn{2}{|c|}{ Model 2} & \multicolumn{2}{|c|}{ Model 3} \\
\hline & without time dummy & with time dummy & without time dummy & with time dummy & without time dummy & with time dummy \\
\hline \multirow[t]{2}{*}{$\Delta \mathrm{ums} 1$} & -0.6684 & -0.2381 & & & & \\
\hline & $(-1.4787)$ & $(-0.5064)$ & & & & \\
\hline \multirow[t]{2}{*}{$\Delta \operatorname{lgm} 1$} & 0.4278 & -0.2607 & & & & \\
\hline & -1.0867 & $(-0.5512)$ & & & & \\
\hline \multirow[t]{2}{*}{$\Delta$ ums2 } & & & $-1.5777^{* *}$ & $-1.1504^{*}$ & & \\
\hline & & & $(-2.6016)$ & $(-1.7313)$ & & \\
\hline \multirow[t]{2}{*}{$\Delta \operatorname{lgm} 2$} & & & $1.4061^{* *}$ & 0.7634 & & \\
\hline & & & -2.3017 & -1.0306 & & \\
\hline \multirow[t]{2}{*}{$\Delta u m s 3$} & & & & & $-1.1331^{\star}$ & -0.4857 \\
\hline & & & & & $(-1.8630)$ & $(-0.7146)$ \\
\hline \multirow[t]{2}{*}{$\Delta \operatorname{lgm} 3$} & & & & & 1.0639 & 0.0826 \\
\hline & & & & & -1.6284 & -0.1019 \\
\hline \multirow[t]{2}{*}{ Igreer } & -0.2241 & 0.0797 & -0.0531 & 0.0553 & -0.2214 & 0.0214 \\
\hline & $(-0.3889)$ & -0.1401 & $(-0.0930)$ & -0.0969 & $(-0.3823)$ & -0.0369 \\
\hline \multirow[t]{2}{*}{ Igprcdt } & $0.7970^{* * *}$ & $0.7515^{\star * *}$ & $0.7802^{* \star \star}$ & $0.7548^{* * *}$ & $0.7866^{* * *}$ & 0.7547 \\
\hline & -13.8882 & -12.8754 & -14.0451 & -13.1113 & -13.6603 & -12.8787 \\
\hline F-statistic & $55.6155^{\text {t** }}$ & $49.0770^{* * *}$ & $61.7090^{* * *}$ & $50.7785^{* * *}$ & $57.3003^{* *}$ & $48.6561^{* * *}$ \\
\hline $\mathrm{R}^{2}$ & 0.7738 & 0.7931 & 0.7915 & 0.7986 & 0.779 & 0.7917 \\
\hline Adj. $\mathrm{R}^{2}$ & 0.7599 & 0.7769 & 0.7787 & 0.7829 & 0.7654 & 0.7755 \\
\hline
\end{tabular}

* 10 percent significant level, " 5 percent significant level, ${ }^{* *} 1$ percent significant level. Dependent Variable is growth rate of real GDP in log transformation. T-statistic is reported in the parenthesis.

Table 10: Result of Unanticipated Money Supply.

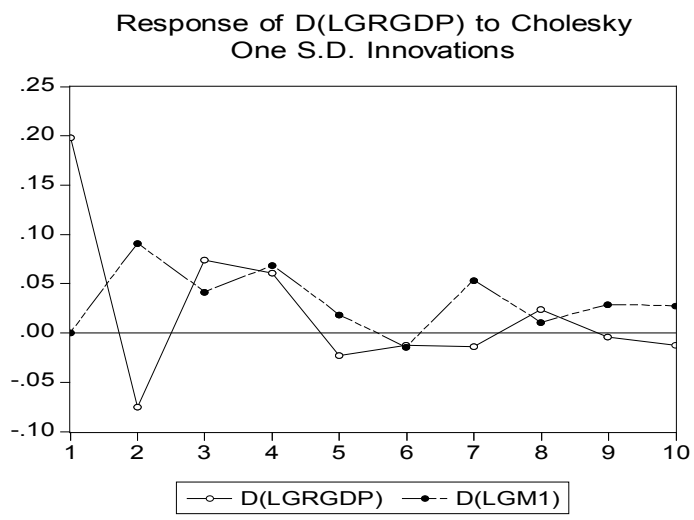

Response of D(LGM1) to Cholesky One S.D. Innovations

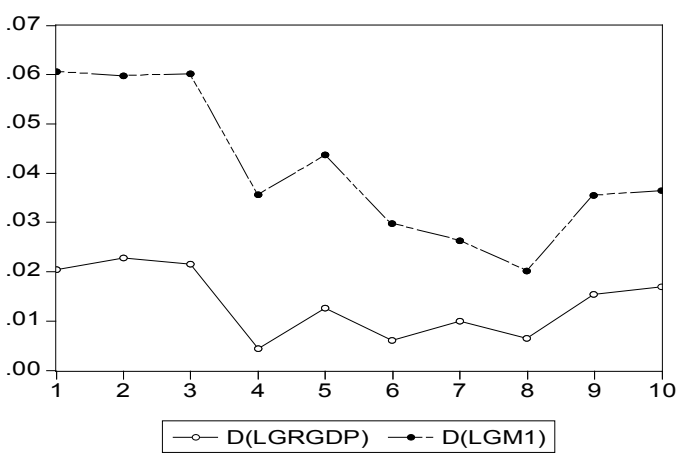

Figure 1: Generalized Impulse Response(s) of Model 1.
Response of D(LGRGDP) to Generalized One S.D. Innovations

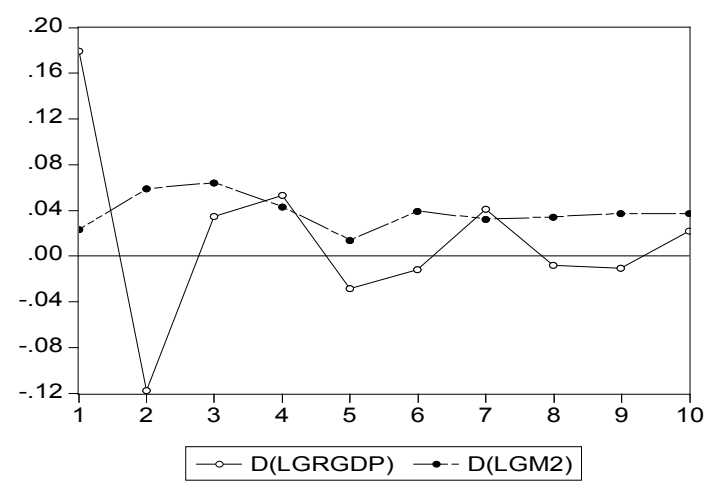

Response of $D($ LGM2) to Generalized One S.D. Innovations

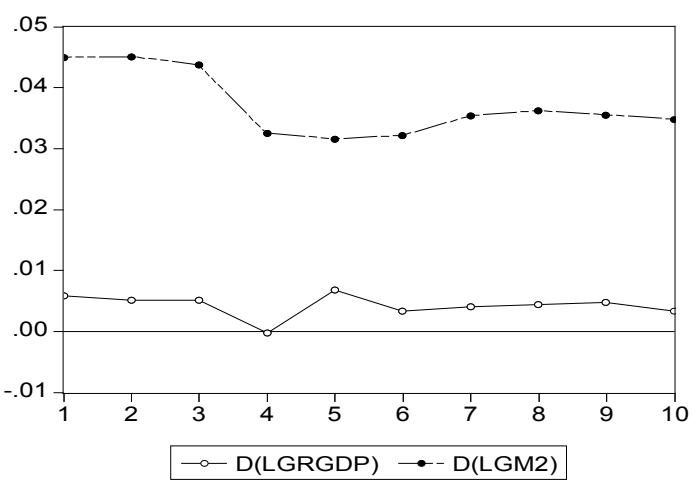

Figure 2: Generalized Impulses Response(s) of Model 2. 
Citation: Sam YH, Geetha C, Chandran VV, Ahmed A (2015) Testing the Neutrality of Money towards Real Output: A Case of Malaysia. Int J Econ Manag Sci 4: 298. doi:10.4172/21626359.1000298

Page 8 of 9
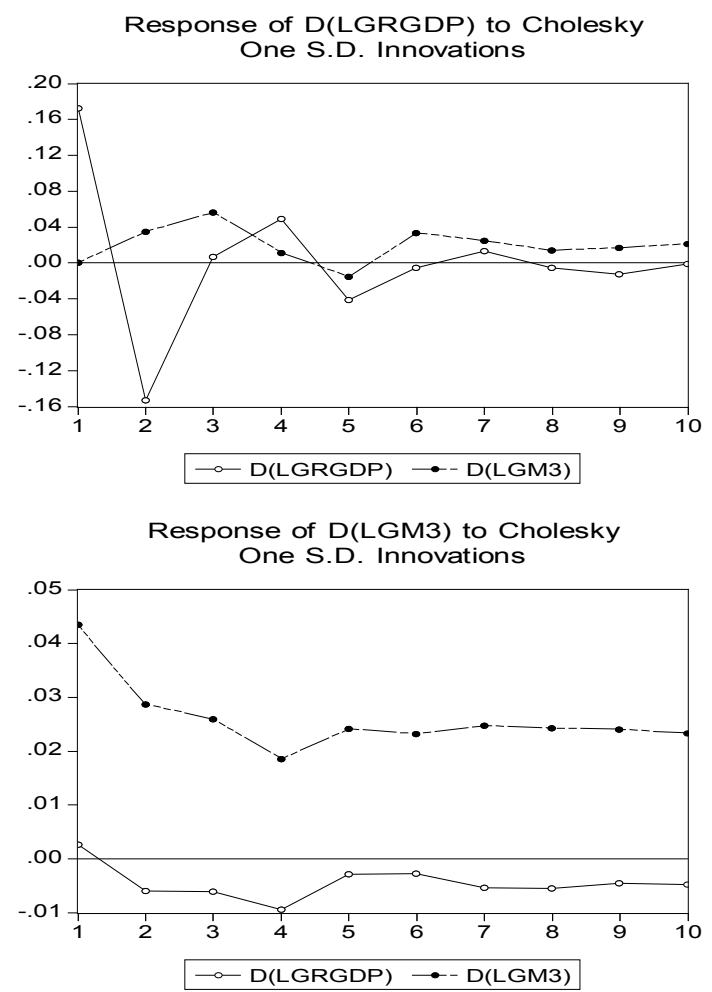

Figure 3: Generalized Impulses Response(s) of Model 3.

compliment the descretionary macroeconomic policy in Malaysia. Since money is non-neutral, it is suggested that, based on nonneutralist point of view, fixed but adjusted exchange rate regime or an intermediate exchange rate regime is more suitable to be implemented in Malaysia. Therefore, the decision on pulling out from fixed exchange rate regime which had implemnted since 1998 had proven a plausible move by the Malaysian policy makers. In a nutshell, the advantages of implementing managed float exchange rate regime with frequent intervention by Bank Negara Malaysia is more than the disadvantages of not implementing it. Although this paper has employed extensive method to examine the relationship between money supply and real output in Malaysia, but, it does not link the findings to the prices, inflation and interest rate in Malaysia. Based on the proposition of neutrality of money, money supply is not able to influence the real output but it does towards the nominal variable such as prices, inflation and interest rate. Therefore, in future, the research should incorporate with the nominal changes in order to provide a more extensive view on how money supply influence Malaysia's economic.

\section{References}

1. Hasan MS (2010) Modeling the Dynamics of Money Income from a Vector Correction Model. The Journal of Developing Areas 43: 233-253.

2. Lucas RE (1975) An Equilibrium Model of the Business Cycle. Journal of Political Economy 83: 1113-1144.

3. Sargent TJ, Wallace N (1975) Rational Expectations, the Optimal Monetary Instrument and the Optimal Money Supply Rule. Journal of Political Economy 83: $241-254$.

4. Mollo MLR, Silva MLF, Torrance TS (2001) Money and Exchange Rate Regimes: Theoretical Controversies. Revista Economia Contemporanea 5: 5-47.
5. Motolese M (2003) Endogenous Uncertainty and the Non-neutrality of Money Economic Theory 21: 317-345.

6. Kurz M (1994) On Rational Belief Equilibria. Economic Theory 4: 859-876.

7. Barro RJ (1977) Unanticipated Monetary Growth and Unemployment in the United States. American Economic Review 67: 101-115.

8. Friedman M (1953) The Case for Flexible Exchange Rates. Chicago: University of Chicago Press.

9. Miller RL, Van HDD (2004) Macroeconomics: Theories, Policies and International Applications ( $3^{\text {rd }}$ eds.), Thomson/South-Western, Pennsylvania.

10. Lucas R (1981) Studies in Business-Cycle Theory. MIT Press, Cambridge

11. Sargent T, Wallace N (1976) Rational Expectation and the Theory of Economic Policy. Journal of Monetary Economics 2: 169 - 183.

12. McKinnon RI (1988) Monetary and Exchange Rates Policies for Internationa Financial Stability: A Proposal. Journal of Economic Perspectives 2: 83-103.

13. Mishkin FS (1996) The Channels of Monetary Transmission: Lessons for Monetary Policy. NBER Working Paper 5464.

14. Williamson J (1992-1993) On Designing an International Monetary System. Journal of Post Keynesian Economics 15: 181-192.

15. Krugman P (1988) Exchange Rate Instability: The MIT Press, London, England

16. BNM (2008) Statement by Governor of Bank Negara Malaysia on the Exchange Rate Regime.

17. Yeap C, Foo YN, Lee E (2015) Cover Story: The Shringgit Dilemma, Kuala Lumpur: The Edge.

18. BNM BNM (2015) Time Series Data on Exchange Rates. Kuala Lumpur: Bank Negara Malaysia.

19. Husain F, Mahmood T (1999) Monetary Expansion and Stock Returns in Pakistan. The Pakistan Development Review 38: 769-776.

20. Thabet EH (2014) Examining the Long Run Relationship between the U.S Money Supply (M2) and the Canadian Stock Market. International Journal of Economics and Finance 6: 180-190.

21. Mustafa K, Ahmed R, Siddiqui AA (2013) Money Supply and Equity Price Movement in Pakistan. European Journal of Business and Management 5 146- 156.

22. Maskay B (2007) Analyzing the Relationship between Change in Money Supply and Stock Market Prices. Honors Project Paper 35.

23. Guttmann R (1994) How Credit Money Shapes the Economy: The United States in a Global System. M.E Sharpe, Armonk, NewYork.

24. Kuttner R (1991) The End of the Laissez-Faire. New York, United States of America.

25. Cooley TF, Hansen GD (1998) The Role of Monetary Shocks in Equilibrium Business Cycle Theory: Three Examples. European Economic Review 42 605-617.

26. Fisher ME, Seater JJ (1993) Long Run Neutrality and Superneutrality in an ARIMA Framework. The American Economic Review 83: 402- 415.

27. King RG, Watson MW (1997) Testing Long Run Neutratlity. Economic Quarterly Volume 83: 69-101.

28. Sulku SN (2011) Testing the Long Run Neutrality of Money in a Developing Country: Evidence from Turkey. Journal of Applied Economics and Business Research 1: 65-74.

29. Serletis A, Koustas Z (1998) International Evidence on Neutrality of Money. Journal of Money, Credit and Banking 30: 1-25.

30. Herwartz H, Reimers HE (2001) Long-Run Links Among Money, Prices and Output: World-Wide Evidence. Discussion Paper of Economic Centre of the Deutsche Bundes bank 14: 1-28.

31. El-Seoud MSA (2014) Testing the Relationship between Money Supply and GDP in Bahrain. Internatonal Journal of Economcis, Commerce and Management 2: 1-16.

32. Zulkhibri M, Majid A (2007) Causality Link between Money, Output and Prices in Malaysia: An Empirical Re-Examination. Applied Econometrics and International Development 7: 211-220. 
Citation: Sam YH, Geetha C, Chandran VV, Ahmed A (2015) Testing the Neutrality of Money towards Real Output: A Case of Malaysia. Int J Econ Manag Sci 4: 298. doi:10.4172/21626359.1000298

Page 9 of 9

33. Habibullah MS, Puah C, Mohamed A (2001) Testing Long Run Neutrality of Money in Malaysia. Jurnal Ekonomi Malaysia 35: 69-83.

34. Bilquees F, Mukhtar T, Sohail S (2012) Dynamic Causal Interactions of Money, Prices, Interest Rate and Output in Pakistan. Journal of Economic Cooperation and Development 33: 37-64.

35. Arintoko (2011) Long-Run Money and Inflation Neutrality Test in Indonesia. Bulletin of Monetary, Economics and Banking 76-99.

36. Falk B (1984) Unanticipated Money Supply Growth and Single-Family Housing Starts in the U.S: 1964-1977. Economic Staff Paper Series 37.

37. Ghazali NA, Wong SM (2005) Money Growth and Malaysian Stock Prices: A Test of Policy Ineffectiveness Proposition. International Journal of Management Studies, 12: 99-114.

38. Thomton J, Molyneux P (1995) Velocity and the Volatility of Unanticipated and Anticipated Money Supply in the United Kingdom. International Economic Journal 9: 61-66.

39. Elliott G, Rothenberg TJ, Stock JH (1996) Efficient Tests for an Autoregressive Unit Root. Econometrica 64: 813-836.

40. Charemza WW, Blangiewicz M (1990) Cointegration in Small Samples:
Empirical Percentiles Drifting Moments and Customized Testing. Oxford Bulletin of Economics and Statistics 52: 303-315.

41. Ahmed AEM (2011) The Long-Run Relationship between Money Supply, Rea GDP, and Price Level: Empirical Evidence from Sudan. Journal of Business Studies Quarterly 2: 68-79.

42. Balke N, Fomby T (1997) Threshold Cointegration. International Economic Review 38: 627-645.

43. Barro RJ, Rush M (1980) Unanticipated Money and Economic Activity. Rationa Expectations and Economic Policy, University of Chicago Press: 23-48.

44. Carns F, Lombra R (1983) Rational Expectations and Short Run Neutrality: A Re-examination of the Role of Anticipated Money Growth. The Review of Economics and Statistics 65: 639-643.

45. Engle RF, Yoo B (1987) Forecasting and Testing in Co-integrated Systems. Journal of Econometrics 35: 143-159.

46. MacKinnon JG (2010) Critical Values for Cointegration Tests. Queen's Economics Department Working Paper: 1227.

47. Mundell RA (1963) Capital Mobility and Stabilization Policy under Fixed and Flexible Exchange Rates. The Canadian Journal of Economics and Political Science 29: 475-485. 